\title{
Innovative Practice of Playing and Singing Course with OBE Concept
}

\author{
Zhao Wenhao \\ College of Music, Hengshui University, Hengshui, Hebei, China
}

Keywords: OBE concept; class ideology, PBL-CBL teaching mode, learning community, innovation and entrepreneurship

\begin{abstract}
The outstanding teaching results-oriented characteristics of OBE's teaching concept have made the certification of teachers' majors in universities more accurate and practical, improving the quality of training music talents in colleges and universities. The reverse teaching design of OBE teaching makes the curriculum around the construction of music talents more targeted and special. Playing and singing is a basic subject in music major with high comprehensiveness and practicability. Comprehensiveness means that it integrates the knowledge of many courses. Practicability refers to that it is the most widely used course in reality, which has the mixed teaching mode. Scenario introduction mobilizes and stimulates the enthusiasm of students. The task-driven classroom practices students' sense of cooperation and the injection of high-level and innovative content highlights the characteristics of the golden class. Students' innovative thinking can be stimulated by the knowledge injection of innovation and entrepreneurship. Ultimately it plays a sublimation role more than the learning effect. This paper combines the mixed teaching used in junior year of the Academy of Music in Hengshui University to carry out a series of innovative teaching practices, which is in line with the real environment to a large extent, so as to improve the learning effect of students.
\end{abstract}

\section{Guidance of OBE Concept and Teacher Certification}

The professional certification of teachers in colleges and universities plays a significant role in improving the quality of talent training in colleges and universities. The vigorous promotion of the OBE teaching concept makes Hengshui University implement systematic teacher's professional certification, further strengthening the training and expansion of music professionals. In this context, the characteristics and requirements of teacher certification majoring in music in colleges and universities should be clarified. With the analysis of the advantages of OBE teaching concept, OBE reverse teaching design and reverse implementation should be carried out in the specific teaching practice of music major under the guidance of talent training of teacher certification. In the cross-development of teacher professional certification and OBE teaching concept, the characteristics of music professional talent training in colleges and universities should be highlighted to create a new era of music education. 


\section{Position of Playing and Singing in Training Program of Music Talents}

Playing and singing is a very important course in music majors. First of all, playing and singing, as the most common course in the music society, is the most popular course in both teaching organized in school music curriculum and various musical activities, such as chorus rehearsal, accompaniment with musical instruments, etc. Second, it is a course with high integration of music majors, which aims to train the ability that students can quickly match the appropriate accompaniment and sing while playing when getting a piece of music. It is a course integrating basic music theory, piano, harmony, vocal music and many other courses, which reflects comprehensive ability. The various courses are interlinked, relying on each other with influence, which shows the professional qualities of musicians in all aspects.

\section{Disadvantages and "Pain Points" of Traditional Teaching Methods of Playing and Singing}

\subsection{Innovative Thinking of Student is Difficult to Stimulate}

The teacher's lecture is usually the main traditional teaching method. Both the accompaniment pattern of musical works and the overall effect of music are explained by teacher in class with the demonstration of the actual performance. Most students will be limited by the teacher's explanation. Students' ability of active thinking and innovating can be severely affected by the preconceived notions. Thus, most students will completely imitate the sound patterns and musical effects played by the teacher. Students who are affected by traditional concepts can easily accept the teacher's explanation without independent cognition and thinking, so the enthusiasm for learning and the innovative thinking are difficult to be stimulated.

\subsection{Lack of Learning Motivation is Caused by Unclear Output Orientation}

There are three aspects affecting the lack of learning motivation.

\subsubsection{The unclear result orientation in teaching design.}

The talent training program, syllabus, and teaching design are interlinked. There is not enough instructional design for the practical application of the skills learned in the traditional way of playing and singing. For example, what is the purpose of learning playing and singing, and in reality, on which occasions will it be used. The learning results are misaligned with the curriculum goals, graduation requirements, and future career requirements due to the lack of creation of actual application environment in the curriculum design lacks. In addition to the unclear curriculum positioning, it also results in insufficient motivation for students to learn at the same time.

\subsubsection{The lack of Student-centeredness in Classroom.}

Traditional teaching of playing and singing is mainly based on the teacher's explanation, which is rough without enough specific exercises and performance steps. The student-centeredness is not carried out, reducing students' enthusiasm for learning. Therefore, students still cannot start in practice, although they have understood the knowledge. In the course design, the difficult points, key points and requirements in the class explained by the teacher have no specific pertinence, which makes the students fear without enough self-confidence in learning this course, and then they feel that it is difficult to achieve and easily give up studying.

\subsubsection{The uncompleted construction of practical classroom.}


As a very practical major, the actual teaching effect of playing and singing can be also affected by the imperfections of practical training in classroom. Playing and singing is more practice in class. However, most of the traditional classroom regards the practice as the exercise of students themselves, which affects the construction of curriculum practice and greatly attenuates the teaching effect.

\subsection{Low Students' Participation in Classroom and Less Learning Community}

Traditional playing and singing emphasizes theoretical explanations with less design and exploration of the practical aspects of the curriculum, which causes the teacher-centeredness. The student is a passive receiver, rather than an active explorer. The passive situation of no thinking, no initiative and no participation in class, as well as the low participation of students in class can be caused because students, as participants in the whole learning process, have no task, which makes them feel relaxed and self-deficiency.

\subsection{Students' Learning Effectiveness Lacks Dynamically "Continuous Improvement"}

The teaching process of traditional playing and singing basically ends at the point that teachers comment on the homework submitted by students with rectification measures, which is also the test of learning achievements through the work of single accompaniment played for teachers. But it cannot be known what level the rectified works have been improved to. If this is the case, there is no further continuous improvement in the student's learning effect, it will be difficult for the student's learning effect to have real guidance and improvement. It is more difficult for students to achieve real results in their learning.

\subsection{Traditional Classroom Content Lacks the Characteristics of "Golden Class"}

There are various problems faced by the traditional teaching: uneven level of students, weak foundation, poor ability of harmony analysis, and disharmonious playing and singing. From the perspective of teachers, basic teaching tasks cannot be guaranteed with so many uncertain factors. However, as the needs of the times and requirements of professional, classroom content needs to move towards building a "golden class" to eliminating the class without high-level, innovation and challenge.

A chart showing the advantages of playing and singing compared with traditional teaching after innovation is as follows.

Table 1. Comparison of Mixed Teaching Flipped Classroom and Traditional Teaching.

\begin{tabular}{|c|c|c|c|c|c|c|c|c|}
\hline & Pre-class & $\begin{array}{l}\text { Classroom } \\
\text { discussion }\end{array}$ & $\begin{array}{l}\text { Classroom } \\
\text { grouping } \\
\text { task }\end{array}$ & $\begin{array}{l}\text { Submission } \\
\text { of } \\
\text { questionnair } \\
\text { e survey }\end{array}$ & $\begin{array}{l}\text { Task } \\
\text { submission } \\
\text { (showing } \\
\text { learning } \\
\text { results on } \\
\text { stage) }\end{array}$ & $\begin{array}{l}\text { Evaluation } \\
\text { with student } \\
\text { participation }\end{array}$ & $\begin{array}{ll}\text { Discussion } & \text { on } \\
\text { problems } & \end{array}$ & $\begin{array}{l}\text { Completion } \\
\text { homework } \\
\text { class }\end{array}$ \\
\hline $\begin{array}{l}\text { Traditional } \\
\text { teaching } \\
\text { mode }\end{array}$ & $\begin{array}{l}\text { Preview } \\
\text { cannot be } \\
\text { guaranteed }\end{array}$ & $\begin{array}{l}\text { Low } \\
\text { participation } \\
\text {, passive }\end{array}$ & $\begin{array}{l}\text { Form with } \\
\text { no content }\end{array}$ & None & $\begin{array}{l}\text { Passive, } \\
\text { unwilling to } \\
\text { show on } \\
\text { stage }\end{array}$ & $\begin{array}{l}\text { Listen to the } \\
\text { teacher's } \\
\text { arrangement, } \\
\text { unwilling to } \\
\text { participate. }\end{array}$ & $\begin{array}{l}\text { Unwilling to } \\
\text { express without } \\
\text { their own point } \\
\text { of view }\end{array}$ & $\begin{array}{l}\text { The amendatory } \\
\text { homework cannot } \\
\text { be further improved }\end{array}$ \\
\hline $\begin{array}{l}\text { Mixed } \\
\text { teaching } \\
\text { mode with } \\
\text { flipped } \\
\text { classroom }\end{array}$ & $\begin{array}{l}\text { Pre-curriculum } \\
\text { with students' } \\
\text { learning of } \\
\text { task points }\end{array}$ & $\begin{array}{l}\text { High } \\
\text { participation } \\
\text { with } \\
\text { enthusiastic } \\
\text { discussion } \\
\text { and mutual } \\
\text { promotion }\end{array}$ & $\begin{array}{l}\text { Take } \\
\text { students' } \\
\text { self-study as } \\
\text { the center } \\
\text { and develop } \\
\text { students' } \\
\text { subjective } \\
\text { initiative }\end{array}$ & $\begin{array}{l}\text { Active } \\
\text { participation } \\
\text { with } 100 \% \\
\text { submission }\end{array}$ & $\begin{array}{l}\text { Everyone } \\
\text { submits the } \\
\text { task, }\end{array}$ & $\begin{array}{l}\text { Students are } \\
\text { very active in } \\
\text { evaluation }\end{array}$ & $\begin{array}{l}\text { Fully express } \\
\text { ideas, change } \\
\text { from passive to } \\
\text { active. }\end{array}$ & $\begin{array}{l}\text { Submit revisions } \\
\text { repeatedly and } \\
\text { interact frequently } \\
\text { between teachers } \\
\text { and students to } \\
\text { improve the quality } \\
\text { of homework. }\end{array}$ \\
\hline
\end{tabular}




\section{Innovative Practice of Mixed Teaching Mode of Playing and Singing based on OBE Concept}

\subsection{Students' Soul Shaped by Class Ideology in "Moistening Things Silently"}

The lack of students' learning motivation has become a persistent deficiency of today's college students. In music majors, students are always regarded as weak, loose and slack in learning ability. As a matter of fact, students are not born good or bad, but it is determined by what kind of teaching methods that teachers choose. Cases that can really touch students can stimulate students' learning motivation, the selection of which directly affects the teaching. In this class, it introduces a very failed music teacher's class to arouse students' reflection in humor and irony, which makes students realize their feelings as a teacher and the responsibility entrusted by the times. The teacher uses three sharp questions to direct the subject to draw the question that "did you work hard today?" Students should face the reality with questions, which truly achieves the class ideology with "moistening things silently" but shocking the soul.

\subsection{Innovative Teaching of PBL-CBL Teaching Mode under "Learning Output" Concept of OBE}

Under the guidance of "learning output" concept of OBE, CBL method is introduced to construct the content module of playing and singing teaching in colleges and universities with cases, which means that the lessons of life music teaching in primary and secondary schools as well as kindergartens are selected as typical teaching cases according to the capability requirements of primary and secondary school music teachers as well as kindergarten teachers. Such a series of typical cases can reconstruct and support the modular teaching content of playing and singing course in colleges and universities.

Under the guidance of "learning output" concept of OBE, PBL method is introduced as the hub to organically organize and coordinate the joint application of various teaching methods in the teaching process of each case module. Specifically, group tasks are carried out as the basic means to organically integrate and infiltrate new teaching methods like collaborative discussion and conversation induction in the task-driven situational case teaching environment, so as to effectively stimulate students' awareness of active exploration and cultivate their innovation ability.

The OBE concept leads accurate evaluation of the teaching effect on playing and singing in colleges and universities. Multiple people, including education experts, senior music teachers in primary and secondary school, senior pre-school teachers and student representatives, should work together with music teachers in colleges and universities according to the specific classification requirements of "learning output" of OBE concept. They can accurately evaluate the application effect of CBL and PBL methods in the teaching of playing and singing, so as to summarize the experience, addressing gaps. In the end, it can promote the perfect application of the two methods in the teaching of playing and singing.

\subsection{Task-based Class Guided by OBE Embodies Multiple-directionality}

The traditional playing and singing courses are mainly explained by teachers. Due to the lack of specific tasks in the teaching process, students' learning motivation is insufficient, while the task-based class significantly improves their motivation, whether it is students' team consciousness or cooperation ability. In this course, the more important thing is that the setting of tasks reflects multiple-directionality. First, students' learning achievements are more than the full embodiment of discipline quality based on OBE concept. In addition, the learning task of the curriculum is also the 
integration and refinement of the professional curriculum group, which means that in a learning task, it not only covers the knowledge of multiple courses, but also the concentrated embodiment of teachers' ability and quality. On the contrary, it has higher requirements for teachers. Not only does a curriculum have a high degree of support for talent training, but also a task-driven curriculum can reflect multiple-directionality.

Flipped classroom has teaching tasks in pre-class, while-class and post-class, which are linked with each other. If students fail to complete one step, it will affect the whole learning process, so students will focus on completing each step of the learning task carefully. Compared with traditional homework, learning tasks are full of problem driving and challenging. Therefore, students have improved their initiative and innovation.

In the pre-class grouping task, students are divided into groups of about 5 people to learn the new music, including harmony function analysis, selection of music accompaniment texture, etc. What is finally submitted to the APP called "Xue Xi Tong" or displayed on the stage is the result of students' self-study, which is a video of students singing while playing new songs. Such teaching effect is very good.

\subsection{Building a Learning Community Goes Together with Culltivating First-class Talents}

The construction of first-class curriculum also focuses on "student-centeredness" with the purpose of cultivating first-class talents. The innovative class is mainly to create a learning community between teachers and students, such as constantly deepening the interaction between teachers and students as well as between students, creating practical situations, improving the evaluation mechanism, etc. Students can promote each other by sharing and discussing their learning results.

When a class is fully student-centered, teacher can change the identity from a leader to a guide and supervisor in the whole teaching process. Usually, the class time will be fragmented. In the 90-minute class time, students' pre-class achievement display can be integrated with evaluation exchange, which can make students transfer from passive recipients to a learning subject with full of autonomy and innovation consciousness. Innovative classroom not only enables students to build a learning community with teachers, but also lays a solid foundation for the goal of cultivating first-class talents.

\subsection{Characteristics of "Golden Class" with two natures and one degree Go Together with "Continuous Improvement"}

The application of flipped classroom promotes the teaching effect and students' mastery of knowledge, so as to make full preparations for building a "golden class". Based on students' learning condition, knowledge with high-level, innovation and challenge can be integrated into the class in the processing and arrangement of playing. For example, for the arrangement of a song, how a basically completed work can change to a better one and a more perfectly completed one: From rich fills as well as wonderful prelude, interlude and finale, to the filling of middle long notes and richer harmony, the connection between knowledge is reflected everywhere. From low-order objectives to high-order objectives, and from the copying of stereotyped knowledge to the arrangement of playing and singing with personality and innovation, they all indicate that students are led to the direction of innovation, when the challenge of knowledge is increased.

While the difficulty of the course continues to improve, it also reflects that the course is a dynamic teaching process with continuous improvement in operation: everywhere reflects the continuous improvement of output-based education from low-order to high-order, from single to innovation, and from learning to output. 


\subsection{Inner Development and Extension of Practical Class Design}

As an application-oriented undergraduate college, it should pay more attention to students' practical application ability of knowledge. The practical class not only fully reflects the "result orientation", but also allows students to deeply experience the real scene of playing and singing, truly achieving the internal development and extension of the class. Internal development means that the course continuously excavates the depth and difficulty of the academic and technical levels. Extension is a form of continuous innovation and broadening curriculum practice and training.

Playing and singing courses in music major test students' ability to improvise accompaniment, play and sing by themselves or accompany others in any environment. Therefore, creating situations for students in the class is bound to stimulate their interest in learning, so as to improve their participation in the class.

The accompaniment environment includes playing and singing by oneself, accompaniment for others and chorus. Teachers create realistic situations for students in the class, taking students as performers to accompany others, which can change the situation that students play homework alone to the teacher, so as to make the forms of homework reporting more diversified. The practical class allows students to truly enter the actual scene of accompaniment for others and chorus, which can let students really feel the finger control when performing and the control of the whole performance psychology, so as to really improve their ability. The accompaniment students will play for the whole class. When evaluation, each student will evaluate the performer. All students have several identities such as singer, audience and teacher with multiple tasks, which greatly improves the students' participation in the class. The practical class further strengthens the output effect of students, widening the platform for successful learning, in order to fully demonstrate the internal development and extension of the class.

\subsection{More Perfect Curriculum Evaluation System}

Compared with the previous single teaching evaluation, the teaching evaluation designed under the OBE concept is more diversified with more attention to process evaluation. In terms of the evaluation, first of all, the evaluation between students is carried out. Each student can express his or her own evaluation of classmates' performance from the perspective of the harmony function system, the selection of accompaniment texture or the piano playing method. After each expression, the teacher starts a guiding speech instead of directly judging that. Students can continue to listen and think with the teacher's enlightenment. Finally, the teacher shows students the explanation video about the song recorded before class rather than drawing comments after all the students show their own views, so that the students can learn through comparison. When the video is finished, the students continue to discuss, which is undoubtedly in-depth. When the accompaniment is done, the first is to let students make self-evaluation and mutual evaluation, and the next is the teacher's summary and comments, which changes the traditional evaluation and assessment method that teacher makes comments alone.

\subsection{Frequent Interaction between Teachers and Students Reflects "Continuous Improvement" to Ensure Learning Results}

Teaching is a continuous process. Mixed teaching mode promotes the frequent interaction between teachers and students, which ensures the teaching effect and the continuous improvement of teaching. The homework feedback of traditional playing and singing is only played to teacher only, and the homework report is only once. Teacher puts forward rectification and adjustment suggestions for the homework, which is usually the end of whole teaching process. After that, a new 
course begins, but there is no feedback about when and how the teacher's rectification opinions on the homework are implemented, and whether the homework is really improved, therefore, students' learning effect is not so good.

The guidance of flipped classroom teaching to students' learning runs through the whole process of pre-class, while-class and post-class. Therefore, the trilogy of flipped classroom can truly improve the students' learning effect.

First of all, in the process of pre-class, students have already understood the knowledge through teaching video. At this time, the teacher can launch the first assignment that the students learn according to the video, completing the assignment and send it to the teacher. Then the teacher puts forward opinions according to the assignment sent by the students. During the class, the teacher can carry out in-depth analysis and discussion on students' homework according to the course content. In the class, the teacher has completed the purification of the content, asking the students to submit their homework with the guidance of the learning effect again, so as to truly improve their learning effect.

Mixed teaching mode increases the interaction between teachers and students, fully realizing that, which enables teachers to follow up students' learning situation timely to promote their learning effect.

\subsection{Full Stimulation of Students' Innovative Thinking through Flipped Classroom}

In the course of playing and singing, there are high requirements for the ability of improvisation, which is a test of students' creativity. It is to arrange an appropriate music texture for the given music without preparation. Because people's understanding and feeling of music are various, everyone's music accompaniment is original and different.

Flipped classroom leave the thinking about music to the students. Before class, the videos of music and accompaniment explanation should be sent to the students. They can learn independently in advance through the videos, which changes the teacher-oriented teaching process and fully develops the students' subjective initiative and learning enthusiasm. If a student does not take the initiative to study, first of all, he or she will not be able to get the usual score, and he or she will not be able to enter the discussion stage of the class. Therefore, students take the initiative to learn in order to get the score, which can mobilize their initiative. Besides, as the content of the course is proposed with no frame and constraints on the music texture, students can match music with any accompaniment through their imagination. Students enjoy innovation in the process of completing their homework, which stimulates their innovative consciousness.

\subsection{The Class Enlightened by Innovation and Entrepreneurship Education}

The education and teaching is a process of continuous innovation, which makes our world better. Innovation is the driving force for national progress. Every works of students' homework will be different when reviewing. They are no longer copies of teachers, but knowledge subjects with full of innovative spirit.

In terms of playing and singing, innovation is the creation of repertoire arrangement, while it is the reform of thinking mode from a large perspective. The innovation of knowledge ontology in the course will rise to the level of innovation and entrepreneurship, and students will be guided and encouraged to carry out innovation and entrepreneurship training projects in the class. From practice to academic level, the subject research project can be constructed with the practical data as the basis. Help students create academic system with training programs. Innovation enlightens the class! 


\section{Conclusion}

Based on the OBE concept, the "student-centeredness, problem-oriented and continuous improvement" run through the whole innovative class of playing and singing. Multiple-directionality of task-driven is a comprehensive following and practice of OBE concept, which continuously condenses with accurate benchmarking from the objectives of curriculum, graduation and talent training. The "continuous improvement" will continuously improve in the internal development and extension of the practical class. The "continuous improvement" not only thoroughly improves the "result orientation", but also makes teaching move forward to innovation on the basis of further consolidation. The playing and singing with "online-offline" mixed teaching mode and three-year construction is becoming more and more mature. It also makes a contribution to the cultivation of first-class talents with the innovation in the "continuous improvement".

\section{Acknowledgement}

This article is the teaching reform and practice project of Higher education in Hebei Province in 2020-2021: The innovative practice research on the Practice of OBE concept in Music Majors in Colleges and universities under the Background of Teacher Training Certification. Project Number: 2020 GJJG392.

This paper is the research outcome of "Innovative Practice of CBL-PBL teaching mode in Song Playing and singing Course under OBE concept", which is funded by the Youth Fund project of Humanities and Social Science research in Hebei Colleges in 2021. (Project Number: SQ2021222)

\section{References}

[1] Spady,W.D.Outcome -based education:critical issues and answers[M].Arlington:American Association of School Admin- istrators.1994

[2] Maidan,Halim A,Safitri R,et al.Impact of Problem -based Learning (PBL) model through Science Technology Society (STS) approach on students' interest[J].Journal of Physics Con-ference Series,2020,1460:012145.

[3] Santos MZD,Otani MAP,Tonhom SFDR,et al. Degree in Nursing : Education Through ProblemBased Learning[J]. Rev Bras Enferm,2019,72(4): 1071-1077.

[4] Shimizu I,Nakazawa H,Sato Y,et al. Does blended problem-based learning make Asian medical students active learners? : a prospective comparative study[J]. BMC Med Educ,2019,19(1):147.

[5] Davies AC,Harris D,Banks-Gatenby A,et al. Problem-based learning in clinical bioinformatics education : Does it help to create communities of practice?[J]. PLoSComputBiol,2019,15(6): e1006746.

[6] Li Y,Wang X,Zhu XR,et al. Effectiveness of problem-based learning on the professional communication competencies of nursing students and nurses :A systematic review[J]. Nurse EducPract, 2019,37 :45-55.

[7] Lennon O,Phelan D,Wallace D,et al. "The more you did, the more it made sense":Problem based learning to improve early evidence-based practice in an undergraduate physiotherapy professional programme[J]. Physiother Res Int,2019,24(3): e1774.

[8] Cavanagh A,Vanstone M,Ritz S. Problems of problem-based learning :Towards transformative critical pedagogy in medical education[J]. Perspect Med Educ,2019,8(1):38-42.

[9] $\mathrm{Hu} X$,Zhang H,Song Y,et al. Implementation of flipped classroom combined with problem-based learning :an approach to promote learning about hyperthyroidism in the endocrinology internship[J]. BMC Med Educ, 2019, 19(1):290.

[10] Dring JC. Problem-Based Learning-Experiencing and understanding the prominence during Medical School: Perspective[J]. Ann Med Surg(Lond), 2019,47 :27-28.

[11] Pu D,Ni J,Song D,et al. Influence of critical thinking disposition on the learning efficiency ofproblem-based learning in undergraduate medical students[J]. BMC Med Educ,2019,19(1):1. 